\title{
Fixed-bed column studies on biosorption of crystal violet from aqueous solution by Citrullus lanatus rind and Cyperus rotundus
}

\author{
Kandaswamy Suyamboo Bharathi • \\ SriKrishna Perumal Thanga Ramesh
}

Received: 2 February 2013/ Accepted: 15 April 2013/Published online: 15 May 2013

(c) The Author(s) 2013. This article is published with open access at Springerlink.com

\begin{abstract}
In this study, fixed-bed column experiments were performed to investigate the biosorption potential of two agricultural wastes, Citrullus lanatus rind and Cyperus rotundus to remove Crystal violet $(\mathrm{CV})$ from aqueous solution. The experiments were conducted to study the effects of important parameters such as bed depth $(10-30 \mathrm{~cm})$, flow rate $\left(10-20 \mathrm{~mL} \mathrm{~min}^{-1}\right)$ and initial dye concentration (10-25 mg L ${ }^{-1}$ ). Different models like Bed Depth Service Time (BDST) model, Thomas model and Yoon-Nelson model were applied to the experimental sorption data. In the biosorption of Crystal violet by both the sorbents, the BDST model fitted well with the experimental data in the initial region of the breakthrough curve. Also, Yoon-Nelson model was found to show good agreement with the experimental kinetic results as compared to the Thomas model. The sorbents were found to be very potential, as it showed good sorption capacities of 46.68 and $54.24 \mathrm{mg} \mathrm{g}^{-1}$ for CV biosorption by Citrullus lanatus rind and Cyperus rotundus. Recovery of dye was made by eluting $1 \mathrm{~N} \mathrm{CH}_{3} \mathrm{COOH}$ through the exhausted column in downward direction.
\end{abstract}

Keywords Biosorption - Crystal violet · Fixed-bed column · BDST · Thomas model · Yoon-Nelson model

K. S. Bharathi $(\bowtie) \cdot$ S. P. T. Ramesh

Department of Civil Engineering, National Institute of

Technology, Tiruchirappalli 620 015, Tamil Nadu, India

e-mail: bharathi.suyamboo@gmail.com

S. P. T. Ramesh

e-mail: stramesh@nitt.edu

\section{Introduction}

Dyes are organic compounds consisting of two main groups of compounds, chromophores (responsible for the color of the dye) and auxochromes (responsible for intensity of the color) (Christie 2001). Dyes usually have a synthetic and complex aromatic structure, which makes them more stable and difficult to biodegrade (Sayan 2006). According to the color index (C.I.) which is managed by the society of dyers and colorists, currently more than 10,000 various types of dyes are synthesized and available in the world (Elkady et al. 2011). It is estimated that approximately $12 \%$ of synthetic dyes are lost during manufacturing and processing operations, and $20 \%$ of these lost dyes enter in the industrial wastewater (Chowdhury et al. 2011a). The dyes used in the textile industries include several structure varieties such as acidic, reactive, basic, disperse, azo, diazo, anthraquinone based and metal complex dyes (Banat et al. 1996).

Crystal violet (CV) or Gentian violet is widely used for dyeing of cotton and silk and in the manufacture of paints and printing inks (Chakraborty et al. 2011; Senthilkumar et al. 2010). It also finds application as a biological stain and is the active ingredient in Gram's stain. The dye is used as a bacteriostatic agent in animal husbandry and veterinary practice and as an additive to poultry feed to inhibit propagation of mold, intestinal parasites and fungus (Senthilkumar et al. 2010; Kumar and Ahmad 2011). Being a protein dye, Crystal violet is also used on most types of adhesive tapes, because conventional powders adhere to the entire sticky side of the tape and are not selective to the latent prints (Ahmad 2009). A considerable amount of dye is lost during manufacturing and processing operations which ultimately enters the water resources through industrial wastewater. Crystal violet is

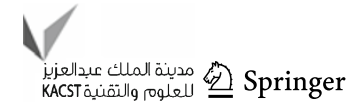


poorly metabolized by microbes, is non-biodegradable and can persist in a variety of environments. Hence, it has been classified as a recalcitrant molecule (Chakraborty et al. 2011). The dye is highly cytotoxic and carcinogenic to mammalian cells. It can cause permanent injury to the cornea and conjunctiva (Chakraborty et al. 2011). Acute exposure to $\mathrm{CV}$ can cause skin irritation, irritation of the digestive tract and may also lead to respiratory and kidney failures (Saeed et al. 2010). Therefore, the treatment of effluents containing such dye is extremely necessary for the protection of both human and public health, as well as the natural environment.

Many treatment processes such as photocatalytic degradation (Sohrabi and Ghavami 2008; Saleiman et al. 2007), electrochemical degradation (Fan et al. 2008), cation exchange membranes (Wu et al. 2008), micellar enhanced ultra filtration (Zaghbani et al. 2008), adsorption/ precipitation processes (Zaghbani et al. 2007), and Fentonbiological treatment (Lodha and Chaudhari 2007) have been applied for the removal of dyes from wastewater. Adsorption has been found to be superior to other techniques for removal of dyes from wastewater in terms of simplicity and flexibility of design, high selectivity and efficiency and high-quality treated effluent (Chowdhury and Saha 2013). Activated carbon is the most widely employed adsorbent for the removal of color from textiles due to its effectiveness and high adsorption capacity; however, its use is still limited because of high operating cost. The need for regeneration and difficulty of separation from wastewater after use are also major concerns associated with activated carbon (Weng et al. 2009). Conversely, biosorption defined as the removal of materials (organic compounds, metal ions, dye molecules, etc.) by inactive, non-living biomass (materials of biological origin) has emerged as an alternative low cost and eco-friendly technology (Farooq et al. 2010).

An economic sorbent is defined as the one which is abundant in nature, or is a by-product or waste from industry, has little or no economic value and requires little processing. Agricultural residues, also called lingo cellulosic biomass resources are defined as a biomass byproduct from the agricultural system and include straws, husks, shell and stalks. These wastes can be divided into two groups: crop residues, which remain in the field after harvest, for example, cotton; agricultural residues, which are the by-products of the industrial processing of crops, for example, rice husk (Tunc et al. 2009). Several million tons of agricultural wastes are being disposed in the world every year through different ways such as incineration, land applications and land filling. Dye adsorption by these wastes may provide an attractive alternative treatment due to their low cost and readily availability (Farooq et al. 2010). A number of studies on removal of dye from aqueous solution using different low-cost materials such as Posidonia oceanic (L.) dead leaves (Cavas et al. 2011), peanut husk (Song et al. 2011), Capsicum annuum seeds (Akar et al. 2011), oil palm shell (Foo and Hameed), cotton seed hull (Qi et al. 2011), pine tree leaves (Deniz and Karaman 2011), waste tea activated carbon (Auta and Hameed 2011), Thespesia populena pods (Arulkumar et al. 2011), Ananas comosus (Chowdhury et al. 2011b), coffee husk-based activated carbon (Ahmad and Rahman 2011), palm kernel fiber (El-Sayed 2011), sugarcane bagasse (Zhang et al. 2011a), treated ginger waste (Kumar and Ahmad 2011), Mangifera indica (Alencar et al. 2012), Jujuba seeds (Reddy et al. 2012), wheat residue (Zhong et al. 2011), peanut hull (Tanyildizi 2011), Oryza sativa (Safa and Bhatti 2011), ground shell powder (Kumar et al. 2013), wheat straw (Zhang et al. 2011b), NaOH-modified rice husk (Chowdhury and Saha 2013), Dithiocarbamated symphoricarpus albus (Kara et al. 2012), cashew nut shell (Senthilkumar et al. 2010), rice straw (Chakraborty et al. 2011), tamarind seed powder (Patel and Vashi 2012), oil palm empty fruit bunch (Auta 2012) have been reported. Despite that many low-cost adsorbents have been studied for decontamination purposes, study on the Citrullus lanatus rind and Cyperus rotundus as economical sorbents for the treatment of wastewater is a win-win strategy because it not only converts the waste into a useful material but it also prevents on-site burning of the waste and saves disposal costs (Weng et al. 2009).

Most of the adsorption studies have been conducted in batch modes which are usually limited to the treatment of small quantities of wastewater (Upendra and Manas 2006). Moreover, batch operations are very easy to apply in the laboratory study, but less convenient for field applications (Hasan et al. 2010). The sorption capacity of the sorbent, obtained from batch equilibrium experiment, is useful in providing fundamental information about the effectiveness of sorbate-sorbent system. However, the data obtained under batch conditions are generally not applicable to most treatment system (such as column operations) where contact time is not sufficiently long for the attainment of equilibrium (Low and Lee 1991). Thus, it is necessary to ascertain the practical applicability of the sorbent in the continuous mode. In order to obtain basic engineering data, continuous flow system is an effective process suitable for large-scale wastewater volumes and cyclic sorption/ desorption: fixed-bed reactor is a simple method for the determination of bed operation life span and regeneration time (Cheknane et al. 2012). Fixed-bed sorption is used to determine the experimental breakthrough curve. In fact, from the industrial point of view, the removal of dyes and/or colored compounds using the adsorption techniques performed in column systems is thought to be very useful due to the adaptability of column systems to versatile processes, 
low reagent handling and accordingly low operational cost coming out (Akar et al. 2011). Reports regarding the removal of pollutants in continuous mode using fixed-bed column are only a few (Batzias and Sidiras 2004).

Thus, the primary objective of this study was to evaluate the performances of Citrullus lanatus rind and Cyperus rotundus for Crystal violet removal from aqueous solution in dynamic flow system. The effects of important design parameters such as feed flow rate, column bed height and initial dye concentration were studied, and the obtained breakthrough curves were analyzed using Bed Depth Service Time (BDST) model, Thomas model and Yoon-Nelson model.

\section{Materials and methods}

Preparation of biosorbents

The biosorbent, Citrullus lanatus rinds, was collected from the local market, Tiruchirappalli, Tamil Nadu, India, as solid waste. The rinds were thoroughly washed with tap water and with distilled water to remove the dirt and earthy materials adhered to the surface. Then it was sliced, spread on trays and kept under hot sun for 5 days. The dried biomass was ground, sieved and stored in air tight container for further use.

The other sorbent, Cyperus rotundus, was collected from the local farmlands in Tiruchirappalli, Tamil Nadu, India. The biosorbent was first thoroughly washed with tap water and again with distilled water to remove the remaining dirt and any unwanted particles and then sun dried and subsequently oven dried at $60^{\circ} \mathrm{C}$ for $24 \mathrm{~h}$ and ground to find powder. No other physical or chemical treatments were given to both the biosorbents prior to experiments. The sorbents were designated as CLR (Citrullus lanatus rind) and CR (Cyperus rotundus) in the further experiments.

\section{Adsorbate}

Crystal violet (CV) used in this study was procured from S.D. Fine-Chem. Ltd. (India) (CI 42555, MF: $\mathrm{C}_{25}$ $\left.\mathrm{H}_{30} \mathrm{CIN}_{3}\right) \lambda_{\text {max }}: 579 \mathrm{~nm}$ ) and used without further purification. Stock dye solution $\left(1,000 \mathrm{mg} \mathrm{L}^{-1}\right)$ was prepared by dissolving $1 \mathrm{~g}$ of the dye in $1 \mathrm{~L}$ of double distilled water. Experimental dye solution of different concentrations was prepared by diluting the stock solution with suitable volume of double distilled water.

Fixed-bed column studies

The continuous flow biosorption experiments were conducted in a glass column of internal diameter $2.5 \mathrm{~cm}$ and length $55 \mathrm{~cm}$. The biosorbents were packed in the column between glass wool and glass beads, which prevented the wash out of CLR and CR. The particle size of both the sorbents was 150 $300 \mu \mathrm{m}$ with a bed depth of $30 \mathrm{~cm}$. The filling weight of CLR and CR were 21.63 and $14.5 \mathrm{~g}$, respectively and the packed density of CLR and CR in the column were 0.1469 and $0.0984 \mathrm{~g} \mathrm{~cm}^{-3}$, respectively. All the experiments were carried out at $303 \pm 1 \mathrm{~K}$. Before operation, the bed was rinsed with distilled water and left overnight to ensure a closely packed arrangement of particles with no void, channels, or cracks. A schematic of a fixed-bed column of the biosorbent for CV biosorption is shown in Fig. 1. Dye solution was fed through the fixed-bed column in a down flow mode. The samples were collected at specified time intervals, and the concentration of CV in the effluent was analyzed using UV/ vis spectrophotometer. Operation of the column was stopped when the effluent $\mathrm{CV}$ concentration exceeded a value of $99.5 \%$ of its initial concentration. The time for breakthrough appearance and shape of the breakthrough curves are very important characteristics for determining the operation and the dynamic response of an adsorption column. Therefore, breakthrough curves, i.e., $\frac{C_{t}}{C_{o}}$ verses times were plotted. The breakthrough time $\left(t_{\mathrm{b}}\right.$, the time at which dye concentration in the effluent reached $\left.1 \mathrm{mg} \mathrm{L}^{-1}\right)$ and bed exhaustion time $\left(t_{\mathrm{e}}\right.$, the time at which dye concentration in the effluent reached $99.5 \%$ of initial dye concentration) were used to evaluate the breakthrough curves.

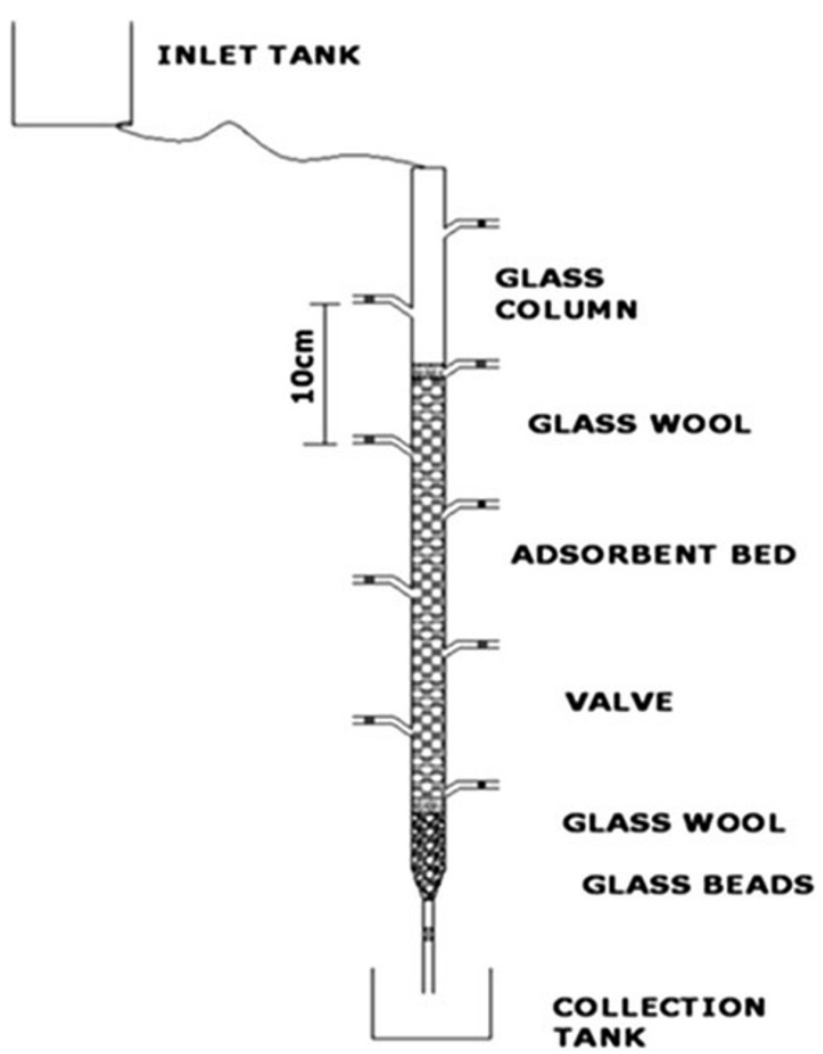

Fig. 1 Schematic diagram of lab-scale column study

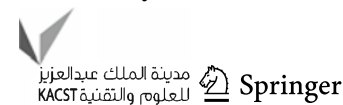


Effect of flow rate, initial $\mathrm{CV}$ concentration and bed depth

For both the sorbents, three initial CV concentrations of 10 , 15 and $25 \mathrm{mg} \mathrm{L}^{-1}$ and three flow rates of 10,15 and $20 \mathrm{~mL} \mathrm{~min}{ }^{-1}$ were investigated at a constant bed depth. The cumulative bed depths studied were 10, 20 and $30 \mathrm{~cm}$.

\section{Desorption study}

For any adsorption process, the most important factors are the recovery of the adsorbent and the regeneration capacity of the adsorbent. Desorption was carried out by $1 \mathrm{~N}$ $\mathrm{CH}_{3} \mathrm{COOH}$ solution through the bed in the downward direction at a flow rate of $13 \mathrm{~mL} \mathrm{~min}^{-1}$, slightly less than the sorption flow rate $15 \mathrm{~mL} \mathrm{~min}^{-1}$.

Characterization of biosorbents

\section{Fourier transform infrared (FTIR)}

A qualitative and preliminary analysis of the main functional groups on the biosorbent surface that might be involved in dye binding can be identified by FTIR as each group has a unique energy absorption band. Therefore, FTIR spectra of CLR and CR, before and after biosorption of $\mathrm{CV}$, were recorded with a FTIR spectrometer (Spectrum BX-II, PerkinElmer, USA). $0.001 \mathrm{~g}$ of dry sample was mixed with $0.5 \mathrm{~g}$ of spectroscopic grade potassium bromide powder in an agate pestle and mortar. The powder was then compressed into a thin $\mathrm{KBr}$ translucent disk under a pressure of $100 \mathrm{~kg} \mathrm{~cm}^{-2}$ for $8 \mathrm{~min}$ with the aid of a bench press. FTIR spectra were then recorded in the wave number range $400-4,000 \mathrm{~cm}^{-1}$.

\section{Scanning electron microscopy (SEM)}

The surface structure of the biosorbent, before and after biosorption, was analyzed by scanning electron microscope (S-300 N, Hitachi, Japan) at an electron acceleration voltage of $25 \mathrm{kV}$. Prior to scanning, the unloaded and dyeloaded CLR and CV samples were mounted on a stainless steel stab with double stick tape and coated with a thin layer of gold in a high-vacuum condition.

\section{Theory}

\section{Modeling of column data}

In the present study, the Bed Depth Service Time (BDST) model (Hasan et al. 2010), Thomas model (Han et al. 2008) and Yoon-Nelson model (Ramesh et al. 2011) were fitted to the dynamic flow experimental data performed in the fixed-bed column to predict the breakthrough curves and to determine the characteristic parameters of the column.

\section{Bed depth service time (BDST) model}

The BDST is a model for predicting the relationship between depths, $\mathrm{X}$ and service time t (Vijayaraghavan and Prabu 2006). This model states that the bed height and service time of a column bear a linear relationship. This model was derived based on the assumption that forces like intra particle diffusion and external mass transfer resistance are negligible and that the adsorbate is adsorbed onto the adsorbent surface directly (Han et al. 2008). This model is used only for the description of the initial part of the breakthrough curve, i.e., up to the breakpoint or 10-50\% of the saturation points (Kundu and Gupta 2006). This BDST model was focused on the estimation of characteristic parameters such as the maximum adsorption capacity and kinetic constant. The original BDST model was carried out by Bohart and Adams and given in Eq. (1) (Singh and Panat 2006)

$\ln \left(\frac{C_{0}}{C_{B}}-1\right)=\ln \left(\exp \left[\frac{K X N_{0}}{v}\right]-1\right)-K C_{0} t$

A linear relationship between bed depth and service time is given by Eq. (2) (Goel et al. 2005)

$t=\frac{N_{0}}{v C_{0}} \mathrm{X}-\frac{1}{K C_{0}} \ln \left(\frac{C_{0}}{C_{B}}-1\right) \ln \mathrm{C}_{\mathrm{o}} \mathrm{C}_{\mathrm{B}}-$

$=\ln \left(\mathrm{eKx} v \mathrm{~N}_{0}-1-\mathrm{KC}\right)$

where $C_{0}$ is the initial concentration of solute $\left(\mathrm{mg} \mathrm{L}^{-1}\right), C_{B}$ the desired concentration of solute at breakthrough $\left(\mathrm{mg} \mathrm{L}{ }^{-1}\right), \mathrm{K}$ the adsorption rate constant $\left(\mathrm{L}^{-1} \mathrm{mg}^{-1} \mathrm{~h}\right)$, $N_{0}$ the adsorption capacity $\left(\mathrm{mg} \mathrm{L}^{-1}\right), \mathrm{X}$ the bed depth of column $(\mathrm{cm}), v$ the linear flow velocity of feed to bed $\left(\mathrm{cm} \mathrm{h}^{-1}\right), t$ the service time of column under above conditions (h). Eq. (2) can be rewritten in the form of a straight line:

$t=a \mathrm{X}-b$

where $a$ is the slope of BDST line $\left(a=\frac{N_{0}}{v C_{0}}\right)$ and the intercept of this equation represened as Eq. (4).

$b=\frac{1}{K C_{0}} \ln \left(\frac{C_{0}}{C_{B}}-1\right)$

Thus, $N_{0}$ and $k$ can be evaluated from slope $(a)$ and the intercept $(b)$ of the plot of $t$ versus $X$, respectively.

The critical bed depth $\left(X_{0}\right)$ is the theoretical depth of adsorbent sufficient to ensure that the outlet solute concentration does not exceed the breakthrough concentration $\left(C_{B}\right)$ value at time $t=0 . X_{0}$ can be calculated as Eq. (5) (Vijayaraghavan and Prabu 2006) 
$X_{0}=\frac{v}{K N_{0}} \ln \left(\frac{C_{0}}{C_{B}}-1\right)$

The BDST model can be extended for the predication of a slope of the model at other flow rates. When the flow rate is changed from $Q$ to a new value, $Q^{\prime}$, the new value of slope $\left(a^{1}\right)$ is obtained by Eq. (6). However, the intercept remains unchanged because it depends on the inlet solute concentration, $C_{0}$ (Taty-Costodes et al. 2005)

$\mathrm{a}^{1}=\frac{a Q}{Q^{1}}$

Thomas model

The Thomas model is one of the most general and widely used models to describe the behavior of sorption process in fixed-bed columns. The model is based on the assumption that the process follows Langmuir kinetics of sorptiondesorption with no axial dispersion (Hasan et al. 2010). Its main limitation is that its derivation is based on secondorder kinetics and considers that sorption is not limited by the chemical reaction but controlled by the mass transfer at the interface (Hasan et al. 2010). This discrepancy can lead to errors when this method is used to model sorption processes in specific conditions.

The model has the following form:

$\frac{C_{t}}{C_{0}}=\frac{1}{\left[1+\exp \frac{K_{T}\left(q m-C_{0} V\right)}{r}\right]}$

Substituting $=t=V / r$ in Eq. (7), it becomes

$\frac{C_{t}}{C_{0}}=\frac{1}{\left[1+\exp \left(K_{T}\left\{\frac{q m}{r}-C_{0} t\right\}\right)\right]}$

It can be rewritten as

$K T\left(\frac{q m}{r}-C_{0} t\right)=\ln \left(\frac{C_{t}}{C_{0}}-1\right)$

This is in the form of

$Y=b-a t$

Having slope $a=K_{T} C_{0}$, intercept $b=\frac{K_{T} q m}{r}$ where $C_{t}$ is effluent concentration $\left(\mathrm{mg} \mathrm{L}^{-1}\right), C_{0}$ is influent concentration $\left(\mathrm{mg} \mathrm{L}^{-1}\right), K_{T}$ is Thomas rate constant $\left(L_{\min } \mathrm{mg}^{-1}\right)$, $\mathrm{q}$ is the maximum biosorption capacity $\left(\mathrm{mg} \mathrm{g}^{-1}\right), m$ is mass of adsorbent $(\mathrm{g}), V$ is effluent volume $(\mathrm{mL})$ and $r$ is flow rate $\left(\mathrm{mL} \mathrm{min}^{-1}\right)$. The constants $K_{T}$ and $q$ can be determined from a plot of $\ln \left(C_{t} / C_{0}-1\right)$ against $t$ (Sivakumar and Palanisamy 2009)

\section{Yoon Nelson model}

This model is mathematically equivalent to the Thomas model, and it has also been applied to a range of concentrations in the effluent between the breakthrough and saturation time of the column (Martín-Lara et al. 2010). This model is based on the assumption that the rate of decrease in the probability of adsorption for each adsorbate molecule is proportional to the probability of adsorbate adsorption and probability of adsorbate breakthrough on the adsorbent. (Han et al. 2009) The linear form of Yoon and Nelson equation regarding a single-component system is expressed as

$\ln \left(\frac{C_{t}}{C_{0}-C_{t}}\right)=K_{\mathrm{YN}} \mathrm{t}-\tau K_{\mathrm{YN}}$

where $K_{\mathrm{YN}}$ is the Yoon-Nelson rate constant; $\tau$ is the time required for $50 \%$ sorbate breakthrough and $t$ is the breakthrough (sampling) time. The parameters $K_{\mathrm{YN}}$ and $\tau$ may be determined from a plot of $\ln \left[C /\left(C_{0}-C_{t}\right)\right]$ versus sampling time $(t)$. The derivation of Eq. (10) was based on the definition that $50 \%$ breakthrough occurs at $t=\tau$. Thus, the sorption bed should be completely saturated at $t=2 \tau$. Owing to the symmetrical nature of breakthrough curves due to the Yoon-Nelson model, the mount of metal being sorbed in the fixed bed is half of the total metal entering the sorption bed within $2 \tau$ period. Hence, the following equation can be obtained for a given bed:

$q_{\mathrm{YN}}=\frac{q_{\mathrm{tot}}}{M}=\frac{\left(\frac{1}{2}\right) C_{0}\left(\frac{Q}{1000}\right)\left(2_{\tau}\right)}{M}=\frac{C_{0} Q_{\tau}}{1000 M}$

This equation also permits to determine the adsorption capacity of the column $\left(q_{\mathrm{YN}}\right)$ as a function of bed height $(Z)$, initial dye concentration $\left(C_{0}\right)$, flow rate $(Q)$, biomass quantity in the column $(M)$ and $50 \%$ breakthrough time $(\tau)$ by using Yoon-Nelson model.

\section{Results and discussion}

Characterization of biosorbents

\section{SEM analysis}

SEM is one of the useful tools to examine the surface morphology of the biosorbent. SEM micrographs were taken before and after CV biosorption by CLR and CR. Figure 2 elucidates the surface structure of CLR and CR before and after $\mathrm{CV}$ biosorption. Before dye uptake, the CLR is characterized by irregular and porous surface (Fig. 2a). Following dye biosorption, pores are absent on the surface of CV-loaded CLR, suggesting biosorption of CV onto CLR (Fig. 2b). As can be seen from Fig. 2c, the $\mathrm{CR}$ biosorbent without contact with dye solution is a more fibrous material presenting some macro porous. The cavities of the fibrous materials were expanded, which should allow the diffusion of the dye molecules through the macro 

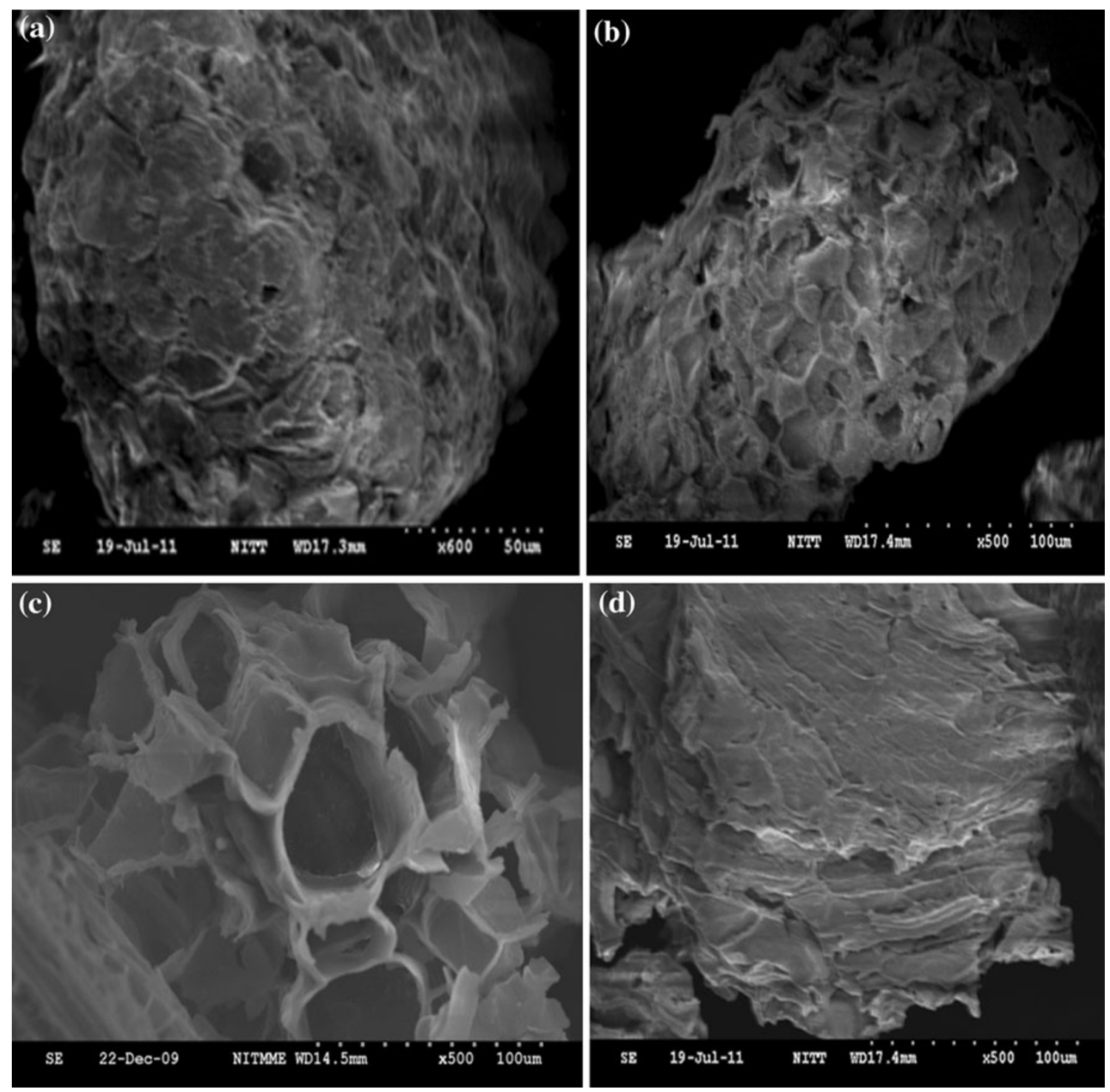

Fig. 2 SEM micrographs of raw and CV loaded CLR and CR

porous of the $\mathrm{CR}$ biosorbent. In addition, the appearance of a molecular cloud over the surface of dye-loaded biosorbent confirms the binding of dye ions to the functional groups present in CR.

\section{FTIR analysis}

The FTIR is an important tool to identify same characteristic functional groups, which are capable of adsorbing dye ions. The FTIR spectra of CLR and CR before and after biosorption of CV are shown in Fig. 3. The FTIR spectrum of CLR (before biosorption) shows several distinct and sharp absorption peaks (Fig. 3a). The peak positions are noticed at 3,929.84, 3,820.95, 3,706.86, 3,389.93, 3,285.60, 2,929.25, 2,239.66, 1,634.19, 1,430.29, $1,247.20$, and $1,057.0 \mathrm{~cm}^{-1}$. The band at $3,929.84 \mathrm{~cm}^{-1}$ is due to $\mathrm{O}-\mathrm{H}$ stretch vibration that is present on the biosorbent (Elkady et al. 2011). The band observed at about $2,929.25 \mathrm{~cm}^{-1}$ could be assigned to $\mathrm{CH}$ stretch shift (Hameed and El-Khaiary 2008). The peak present at $1,430.29 \mathrm{~cm}^{-1}$ represents the $\mathrm{CH}_{2}$ deformation (Hameed and El-Khaiary). The peak around 1,634.19 corresponds to $\mathrm{C}=\mathrm{O}$ stretch (Hameed and Ahmad 2009). While the band at $1,247.20 \mathrm{~cm}^{-1}$ corresponds to $\mathrm{Si}-\mathrm{C}$ stretch (Hameed et al. 2008), and the band at $1,057.0 \mathrm{~cm}^{-1}$ represents $\mathrm{C}-\mathrm{OH}$ stretching vibration deformation (Tan et al. 2008). From Fig. 3b, after the biosorption of CV by CLR, it can be concluded that some of these peaks are shifted or disappeared and new peaks are also detected. These changes observed in the spectrum indicated the possible involvement of those functional groups on the surface of the CLR in sorption process. 
(a)

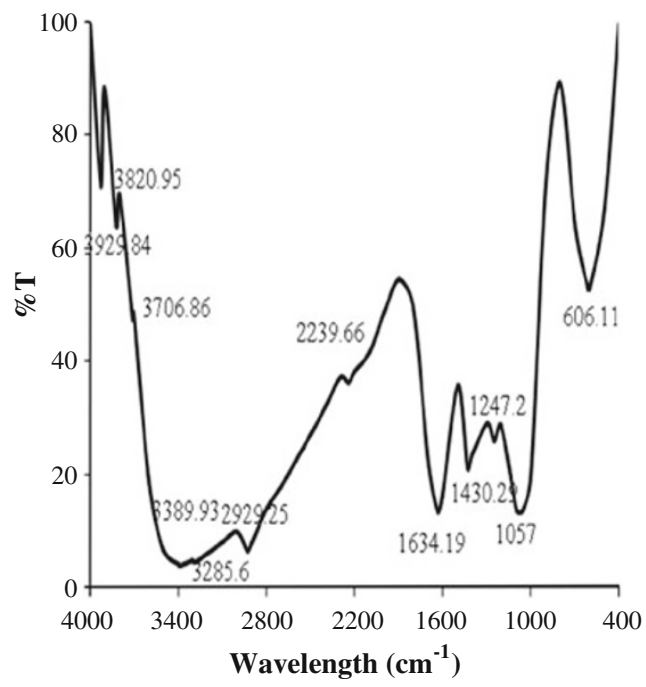

(c)

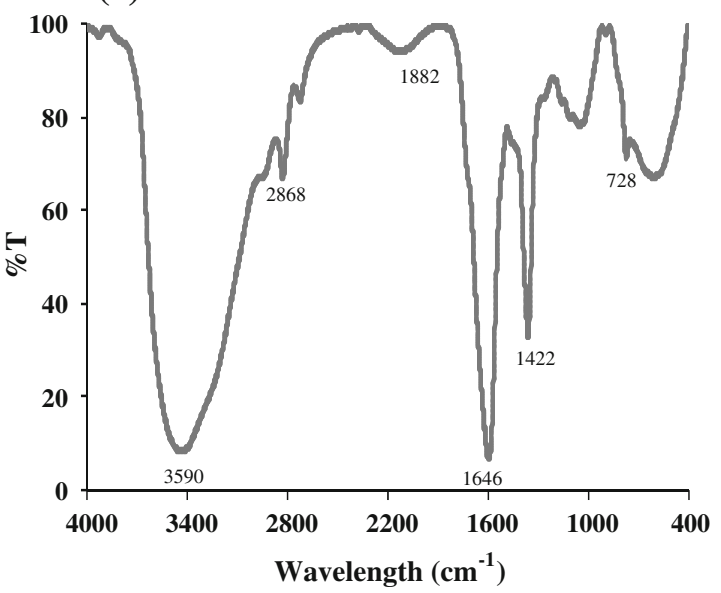

(b)

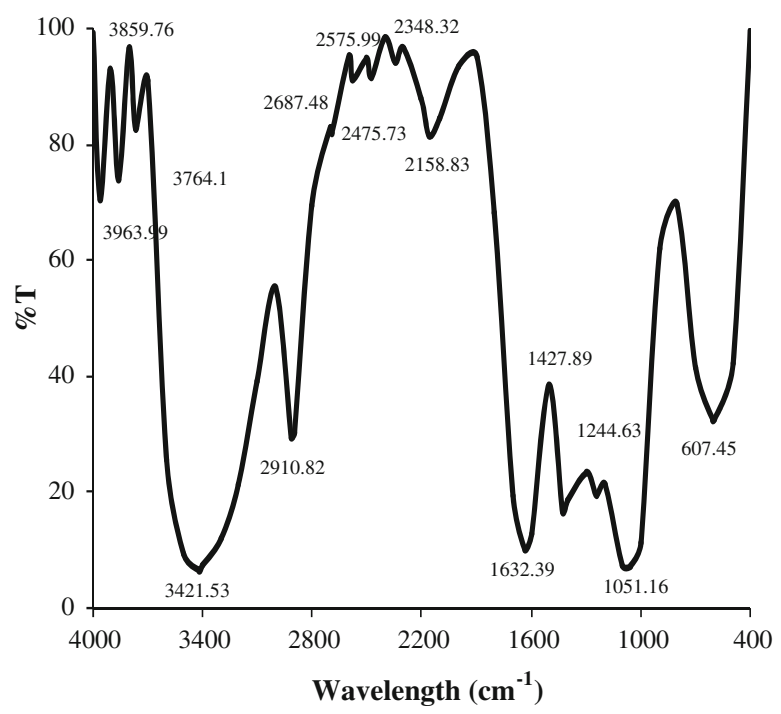

(d)

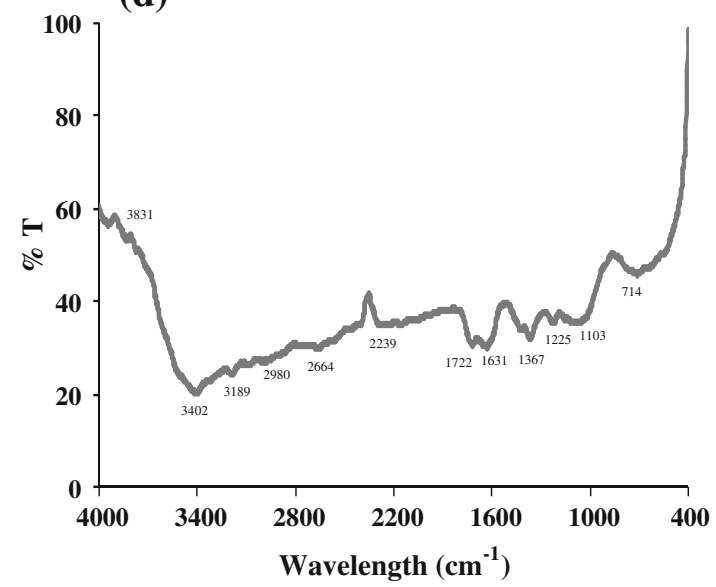

Fig. 3 FTIR spectrum of raw and CV loaded CLR and CR

The FTIR spectra of CR before CV biosorption were performed in the range of $400-4,000 \mathrm{~cm}^{-1}$ to explore the surface characteristics of the biosorbent. Figure $3 \mathrm{c}$ illustrates the FTIR spectrum of the CR before CV biosorption. Cyperus rotundus consists of various functional groups on its surfaces. The main functional groups found were $\mathrm{O}-\mathrm{H}$ stretching vibration of hydroxylic functional groups including hydrogen bonding which was detected at band width of $3,415-3,420 \mathrm{~cm}^{-1}$ (Mohd Azmier and Nazira Khabibor 2011). The intensities of peaks at $2,850 \mathrm{~cm}^{-1}$ were ascribed to $-\mathrm{CH}_{2}$ stretching vibrations (Tamer et al. 2010). The band at $1,590 \mathrm{~cm}^{-1}$ was attributed to $-\mathrm{NH}_{2}$ deformation (Dotto and Pinto 2011). In the FTIR of dye loaded CR (Fig. 3d), the broad and intense band ranging from 3,831 to $3,189 \mathrm{~cm}^{-1}$ can be ascribed to the hydrogen bonded -OH vibrations of the cellulosic structure of CR. The peaks at 2,980 and $714 \mathrm{~cm}^{-1}$ are due to $-\mathrm{CH}$ stretching vibration (Chowdhury et al. 2011a). The other prominent peaks are due to $-\mathrm{NH}_{2}$ and $-\mathrm{C}-\mathrm{O}(1,631$ and $1,367 \mathrm{~cm}^{-1}$, respectively). From the FTIR analysis, it is clear that the functional groups present on the surface of the biosorbents might involve in the dye sorption process.

\section{Column studies}

Effect of bed height

In order to determine the effect of bed height on the breakthrough curve, dye solution having influent $\mathrm{CV}$ concentration $25 \mathrm{mg} \mathrm{L}^{-1}$ and flow rate $10 \mathrm{~mL} \mathrm{~min}^{-1}$ was passed through the column by varying the bed height. The breakthrough curves obtained for $\mathrm{CV}$ biosorption onto CLR and CR at different bed heights are shown in Fig. 4a 

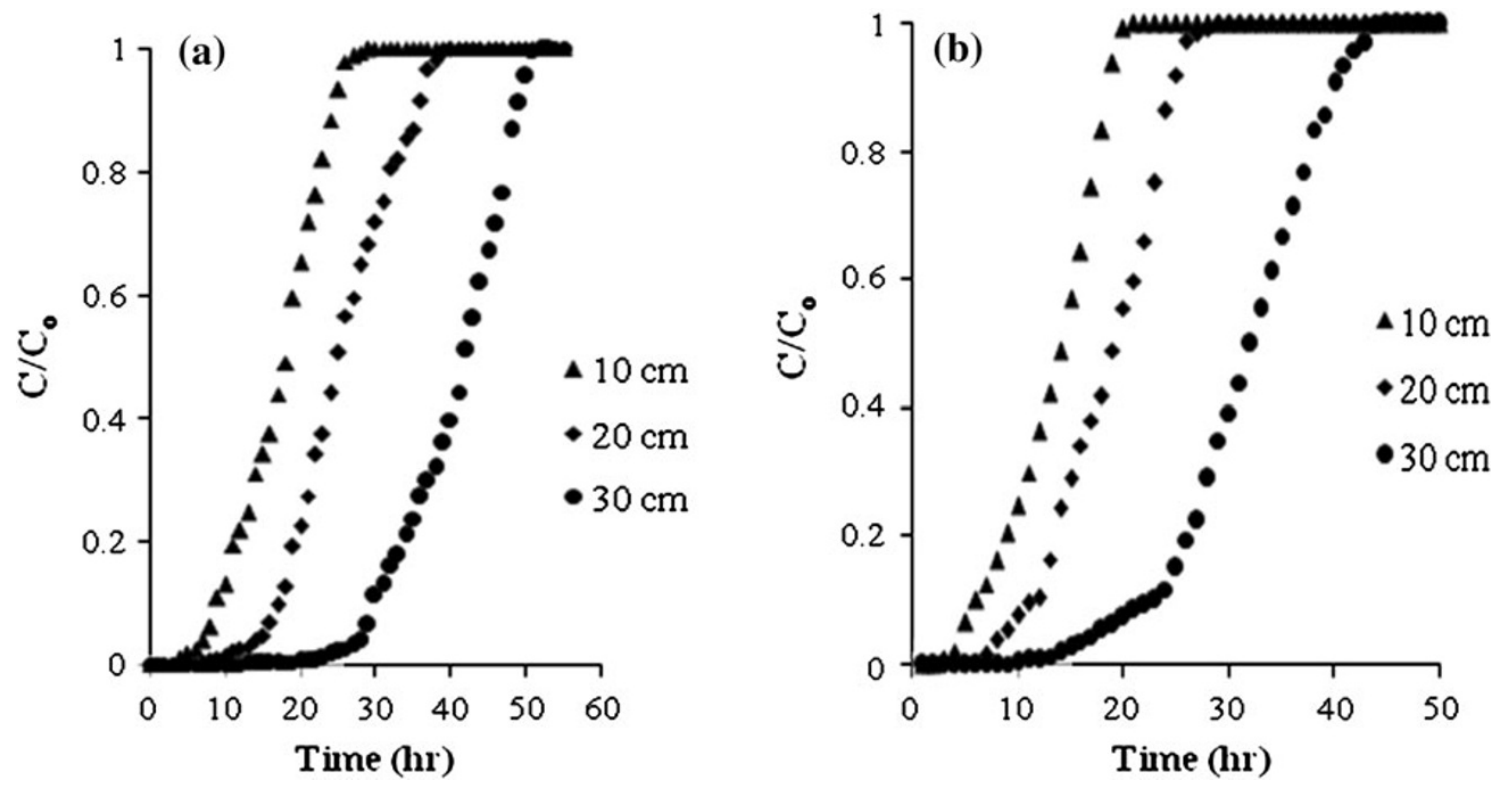

Fig. 4 Breakthrough curves for CV biosorption onto CLR and CR at different bed heights (flow rate $=10 \mathrm{~mL} \mathrm{~min}^{-1}$, initial dye concentration $=25 \mathrm{mg} \mathrm{L}^{-1}$ )

and $b$, respectively. From the figure, it was observed that the breakthrough time varied greatly with bed height. The breakthrough time increased from 9 to $30 \mathrm{~h}$ for CLR and 5 to $24 \mathrm{~h}$ for $\mathrm{CR}$ with increasing bed height from 10 to $30 \mathrm{~cm}$. The mass of the sorbent forming the homogeneous fixed bed is proportional to the bed height, and as a result the number of sorption sites increases with the increase in bed height leading to a larger sorption capacity of the reactor (Hamdaoui 2006). The slope of the breakthrough curve decreased with increasing bed height which resulted in a broadened mass transfer zone. At lower adsorbent bed height, axial dispersion phenomenon predominated and reduced the diffusion of $\mathrm{CV}$ adsorbate (Foo and Hameed 2012). Higher uptake was observed at the highest bed height due to an increase in the surface area of the biosorbent, which provided more binding sites for the sorption (Vijayaraghavan et al. 2004). Also, as the bed height is increased, the dye molecules have more time to contact with the biosorbent resulting in higher dye removal efficiency (Saha et al. 2011)

\section{Effect of flow rate}

Flow rate is an important parameter in evaluating the performance of a biosorption process, particularly for continuous treatment of wastewater on industrial scale (Saha et al. 2011). Therefore, the effect of flow rate on biosorption of CV by CLR and CR was studied by varying the flow rates from 10 to $20 \mathrm{~mL} \mathrm{~min}{ }^{-1}$ and keeping the initial dye concentration $25 \mathrm{mg} \mathrm{L}^{-1}$ and bed height $(30 \mathrm{~cm})$ constant. The effect of flow rate on breakthrough performance at the above operating condition for CLR and $\mathrm{CR}$ is shown in Fig. 5a and b, respectively. From the figure it can be seen that, the breakthrough time as well as the biosorption efficiency of CLR and CR was lower at higher flow rate. As the flow rate increased from 10 to $20 \mathrm{~mL} \mathrm{~min}{ }^{-1}$, the breakthrough time decreased from 30 to $8 \mathrm{~h}$ for CLR and 24 to $7 \mathrm{~h}$ for CR. This is due to the fact that at higher flow rate the contact time of the dye with the biosorbent surface is very short, and hence the dye molecules do not have enough time to capture the binding sites on the biosorbent surface or diffuse into the pores of the biosorbent, leaving the column before equilibrium occurs (Ahmad and Hameed 2010). However, the breakthrough curve became steeper when the flow rate was increased with which the breakthrough time and the dye removal efficiency decreased. But, when the flow rates were low, the external mass transfer controlled the process and it was also ideal for intra particle diffusion system. Thus, the lower flow rates, the more effective was the diffusion process and higher was the residence time of the sorbate, which ultimately resulted in high sorption capacity (Vijayaraghavan et al. 2004).

\section{Effect of initial dye concentration}

The effect of initial CV concentration (10, 15 and $25 \mathrm{mg} \mathrm{L}^{-1}$ ) on the biosorption of CV by CLR and CR at a constant bed height $30 \mathrm{~cm}$ and flow rate $20 \mathrm{~mL} \mathrm{~min}^{-1}$ is shown in Fig. 6a and b, respectively. From the figure it can be observed that, as the initial $\mathrm{CV}$ concentration increased from 10 to $25 \mathrm{mg} \mathrm{L}^{-1}$, the breakthrough and exhaustion 

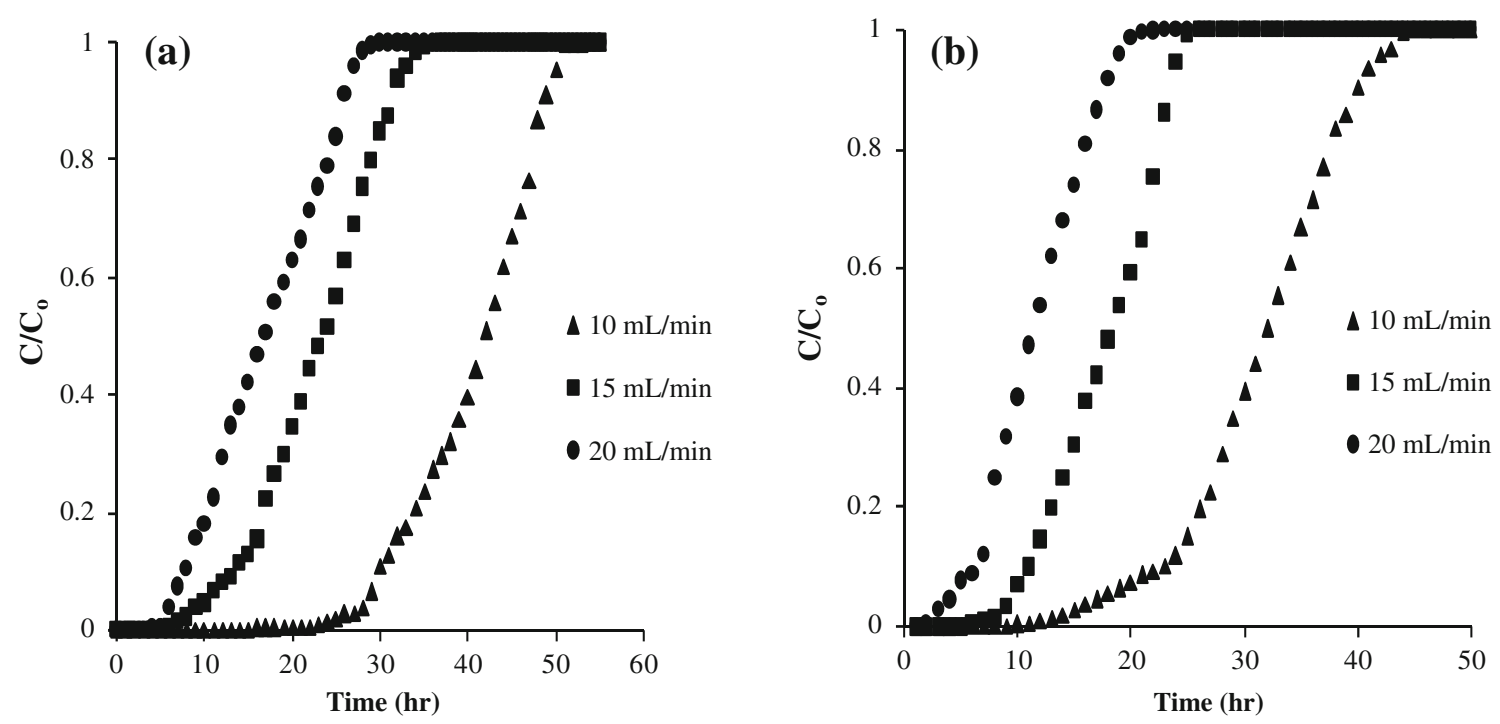

Fig. 5 Breakthrough curves for $\mathrm{CV}$ biosorption onto CLR and CR at different flow rates (bed depth $=30 \mathrm{~cm}$, initial dye concentration $=25 \mathrm{mg} \mathrm{L}^{-1}$ )
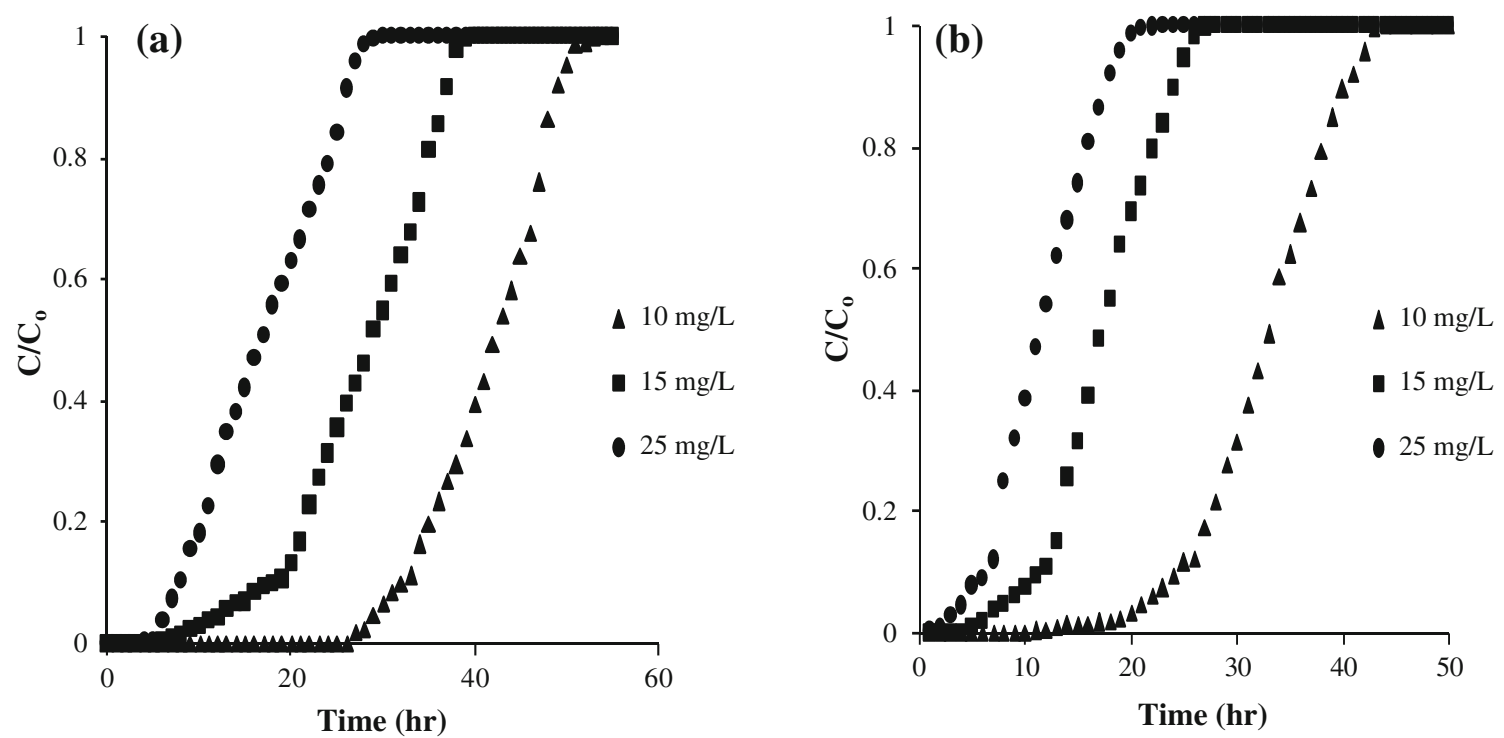

Fig. 6 Breakthrough curves for $\mathrm{CV}$ biosorption onto $\mathrm{CLR}$ and $\mathrm{CR}$ at different initial dye concentration (bed depth $=30 \mathrm{~cm}$, flow rate $=20 \mathrm{~mL} \mathrm{~min}^{-1}$ )

time decreased considerably. In the biosorption of CV by CLR, the breakthrough time decreased from 34 to $8 \mathrm{~h}$ and exhaustion time decreased from 49 to $26 \mathrm{~h}$; whereas in the biosorption of $\mathrm{CV}$ by $\mathrm{CR}$, the breakthrough time and exhaustion time decreased from 26 to $7 \mathrm{~h}$ and 41 to $18 \mathrm{~h}$, respectively. This is due to the fact that high dye concentration leads to quick saturation of the sorbent, which in turn leads to the earlier breakthrough and exhaustion time (Hasan et al. 2010). From the figure, it can also be seen that more favorable and steep breakthrough curves were obtained at high influent CV concentration. These results demonstrated that the change in concentration gradient affects the saturation rate and breakthrough time (Goel et al. 2005). This can also be explained by the fact that more sorption sites were being covered as the concentration of the dye increases (Han et al. 2009).

Application of Bed Depth Service Time (BDST) model

The experimental results obtained from CV biosorption in a column by CLR and CR were fitted to the BDST model to determine the biosorption capacities and kinetic constants. 

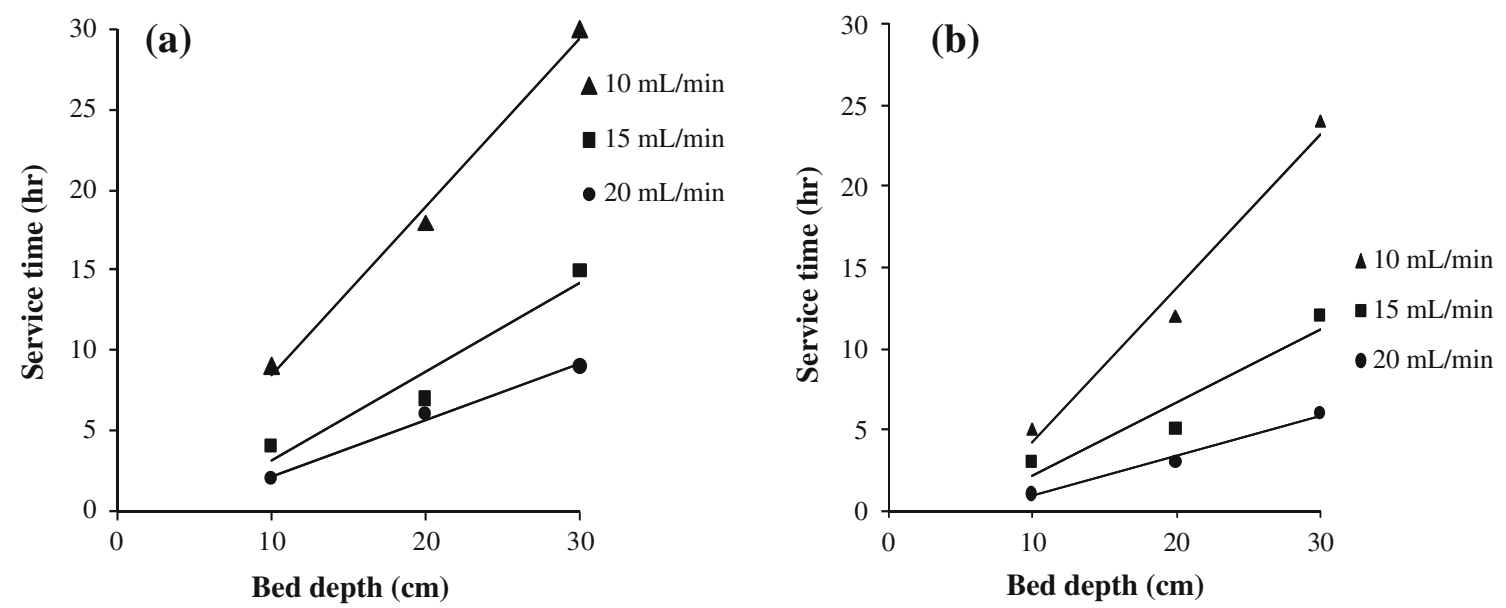

Fig. 7 Bed depth service time plot for CV biosorption onto CLR and CR (initial CV concentration $=25 \mathrm{mg} \mathrm{L}^{-1}$ )

Table 1 Bed depth service time (BDST) model parameters for the sorption of CV by CLR and CR

\begin{tabular}{lllllll}
\hline Sorbents & $\begin{array}{l}\text { Flow rate } \\
\left.(\mathrm{mL} \mathrm{min})^{-1}\right)\end{array}$ & $k\left(\mathrm{~L} \mathrm{mg}^{-1} \mathrm{~h}^{-1}\right)$ & $\begin{array}{l}N_{0} \\
(\mathrm{mg} / \mathrm{L})\end{array}$ & $\begin{array}{l}X_{0} \\
(\mathrm{~cm})\end{array}$ & $R^{2}$ & $q\left(\mathrm{mg} \mathrm{g}^{-1}\right)$ \\
\hline CLR & 10 & 0.03 & 5.02 & 1.9 & 0.99 & 34.15 \\
& 15 & 0.04 & 3.94 & 3.8 & 0.94 & 26.82 \\
& 20 & 0.06 & 3.34 & 4.2 & 0.99 & 22.75 \\
$\mathrm{CR}$ & 10 & 0.02 & 4.54 & 4.58 & 0.98 & 46.14 \\
& 15 & 0.03 & 3.22 & 5.14 & 0.91 & 32.76 \\
& 20 & 0.05 & 2.38 & 6.67 & 0.99 & 24.25 \\
\hline
\end{tabular}

For this purpose, the service time, i.e., the exhaustion time of the column corresponding to bed height 10,20, and $30 \mathrm{~cm}$ at three flow rates, i.e., 10,15 , and $20 \mathrm{~mL} \mathrm{~min}^{-1}$ at a constant influent $\mathrm{CV}$ concentration $25 \mathrm{mg} \mathrm{L}^{-1}$ were recorded. A plot of service time versus bed depth at different flow rates in the biosorption of CV by CLR and CR is shown in Fig. 7a and b, respectively. From the slope and intercept of these BDST plot, the BDST parameters viz. sorption rate constant $(k)$, sorption capacity $\left(N_{0}\right)$, and critical bed depth $\left(X_{0}\right)$ were calculated and are listed in Table 1. High values of correlation coefficient $\left(R^{2}\right)$ (Table 1) showed that the variation of the service time with the bed depth is highly linear for all the systems, thus, indicating the validity of the BDST model when applied to the continuous column studies. The rate constant calculated from the intercept of the BDST plot characterizes the rate of solute transfer from the liquid phase to the solid phase (Hasan et al. 2010). It can be seen from the Table 1 that the values of the rate constant, $k$, were $0.03,0.04$, and 0.06 for CLR and $0.02,0.03$, and 0.05 for CR at flow rates 10,15 , and $20 \mathrm{~mL} \mathrm{~min}{ }^{-1}$, respectively. The values of the rate constants showed an increasing trend with the increase in flow rate indicating that the overall system kinetics was
Table 2 Parameters of Thomas model for the sorption of CV by CLR and CR

\begin{tabular}{|c|c|c|c|c|c|}
\hline Biosorbents & $\begin{array}{l}\text { Flow } \\
\left(\mathrm{mL} \min ^{-1}\right)\end{array}$ & $\begin{array}{l}\text { Bed } \\
\text { depth } \\
\text { (cm) }\end{array}$ & $k_{\mathrm{Th}}$ & $R^{2}$ & $q\left(\mathrm{mg} \mathrm{g}^{-1}\right)$ \\
\hline \multirow[t]{9}{*}{ CLR } & \multirow[t]{3}{*}{10} & 10 & $1.6 \times 10^{-4}$ & 0.98 & 46.68 \\
\hline & & 20 & $1.2 \times 10^{-4}$ & 0.98 & 37.61 \\
\hline & & 30 & $1.6 \times 10^{-4}$ & 0.98 & 22.43 \\
\hline & \multirow[t]{3}{*}{15} & 10 & $1.6 \times 10^{-4}$ & 0.96 & 43.92 \\
\hline & & 20 & $1.6 \times 10^{-4}$ & 0.97 & 29.49 \\
\hline & & 30 & $1.6 \times 10^{-4}$ & 0.96 & 27.31 \\
\hline & \multirow[t]{3}{*}{20} & 10 & $2 \times 10^{-4}$ & 0.96 & 39.74 \\
\hline & & 20 & $1.6 \times 10^{-4}$ & 0.99 & 29.61 \\
\hline & & 30 & $1.6 \times 10^{-4}$ & 0.98 & 28.80 \\
\hline \multirow[t]{9}{*}{$\mathrm{CR}$} & \multirow[t]{3}{*}{10} & 10 & $2.4 \times 10^{-4}$ & 0.98 & 53.79 \\
\hline & & 20 & $2.8 \times 10^{-4}$ & 0.96 & 30.37 \\
\hline & & 30 & $2.8 \times 10^{-4}$ & 0.97 & 25.44 \\
\hline & \multirow[t]{3}{*}{15} & 10 & $2 \times 10^{-4}$ & 0.98 & 49.65 \\
\hline & & 20 & $2 \times 10^{-4}$ & 0.99 & 30.68 \\
\hline & & 30 & $2.4 \times 10^{-4}$ & 0.96 & 28.27 \\
\hline & \multirow[t]{3}{*}{20} & 10 & $2 \times 10^{-4}$ & 0.96 & 43.85 \\
\hline & & 20 & $1.6 \times 10^{-4}$ & 0.98 & 33.03 \\
\hline & & 30 & $2 \times 10^{-4}$ & 0.95 & 28.67 \\
\hline
\end{tabular}

dominated by external mass transfer in the initial part of the sorption in the column. In the biosorption of $\mathrm{CV}$ by CLR and CR, it has been found that the sorption capacity decreased with the increase in flow rate. The sorption capacity was reduced from 5.02 to $3.34\left(\mathrm{mg} \mathrm{cm}^{3}\right)^{-1}$ for CV biosorption by CLR and 4.54 to $2.39\left(\mathrm{mg} \mathrm{cm}^{3}\right)^{-1}$ for $\mathrm{CV}$ biosorption by CR. The values of $k$ and $N_{0}$ indicated that CLR and CR can be used as an efficient biosorbent for the removal of $\mathrm{CV}$ from aqueous solution. The values of the critical bed depth for CV biosorption by CLR and CR at 

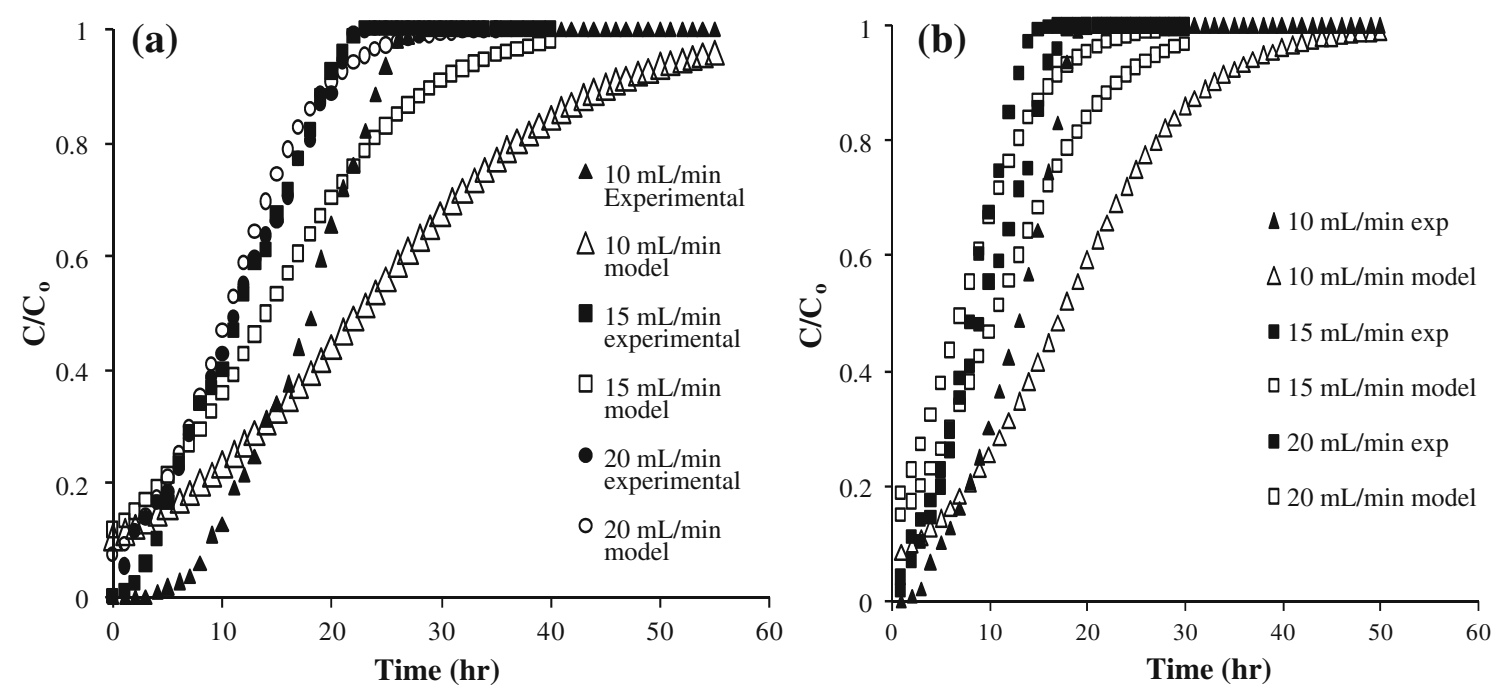

Fig. 8 Experimental and Thomas model predicted breakthrough curves at $10 \mathrm{~cm}$ depth for different flow rates (initial CV concentration $=25 \mathrm{mg} \mathrm{L}^{-1}$ )

different flow rates are given in Table 1. The value of critical bed depth was found to increase from 1.9 to $4.2 \mathrm{~cm}$ for CLR and 4.6 to $6.7 \mathrm{~cm}$ for CR as the flow rate increased from 10 to $20 \mathrm{~mL} \mathrm{~min}^{-1}$. The amount of $\mathrm{CV}$ biosorbed by CLR and CR in unit of $\mathrm{mg} \mathrm{g}^{-1}$ can be calculated by dividing $N_{0}$ with bulk density of CLR and CR in the column. This produced $34.15,26.82$, and $22.75 \mathrm{mg} \mathrm{g}^{-1}$ for CV biosorption by CLR and 46.14, 32.76, and $24.25 \mathrm{mg} \mathrm{g}^{-1}$ for CV biosorption by CR for flow rates of 10,15 and $20 \mathrm{~mL} \mathrm{~min}{ }^{-1}$ respectively.

Application of Thomas model

Thomas model was applied to the sorption kinetic data at three different flow rates, i.e., 10,15 , and $20 \mathrm{~mL} \mathrm{~min}^{-1}$ at an initial dye concentration of $25 \mathrm{mg} \mathrm{L}^{-1}$ and bed height of $10 \mathrm{~cm}$ for the sorption systems of CV by both CLR and CR. The Thomas rate constant $\left(k_{T}\right)$ and the bed capacity $\left(q_{0}\right)$ were calculated from the slope and intercept of the plot between $\ln \left(C_{0} / C_{t}-1\right)$ versus $t$ at different flow rates. The calculated values of $k_{T}$ and $q_{0}$ along with the regression coefficients are presented in Table 2 . The relatively high $R^{2}$ values at all the operating conditions suggested that the Thomas model was suitable for describing the column biosorption data of CV by CLR and CR. As can be seen from the Table 2, at a constant depth of $10 \mathrm{~cm}$, increased flow rate from 10 to $20 \mathrm{~mL} \mathrm{~min}{ }^{-1}$ reduced the maximum CV biosorption capacity by CLR from 46.68 to $39.74 \mathrm{mg} \mathrm{g}^{-1}$ and from 53.79 to $43.85 \mathrm{mg} \mathrm{g}^{-1}$ by CR. This is due to the fact that, at a higher flow rate, the adsorption capacity was lower due to insufficient residence time of the solute in the column and diffusion of the solute into the pores of the adsorbent, and therefore the solute left
Table 3 Parameters of Yoon-Nelson model for the sorption of CV by CLR and CR

\begin{tabular}{|c|c|c|c|c|c|c|}
\hline Biosorbents & 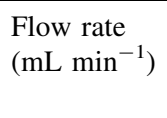 & $\begin{array}{l}\text { Bed } \\
\text { depth } \\
\text { (cm) }\end{array}$ & $k_{\mathrm{YN}}$ & $\tau(\min )$ & $R^{2}$ & $q\left(\mathrm{mg} \mathrm{g}^{-1}\right)$ \\
\hline \multirow[t]{7}{*}{ CLR } & & & 0.004 & 673.25 & 0.98 & 46.68 \\
\hline & \multirow[t]{3}{*}{10} & 10 & 0.003 & 1084.66 & 0.98 & 37.61 \\
\hline & & 20 & 0.004 & 2602.5 & 0.96 & 23.40 \\
\hline & & 30 & 0.004 & 844.5 & 0.96 & 43.92 \\
\hline & \multirow[t]{3}{*}{15} & 10 & 0.004 & 1134.25 & 0.96 & 29.49 \\
\hline & & 20 & 0.004 & 1575.5 & 0.96 & 27.31 \\
\hline & & 30 & 0.005 & 1129.2 & 0.96 & 39.15 \\
\hline \multirow[t]{12}{*}{$\mathrm{CR}$} & \multirow[t]{3}{*}{20} & 10 & 0.004 & 1641.5 & 0.99 & 29.61 \\
\hline & & 20 & 0.004 & 2562.5 & 0.99 & 28.45 \\
\hline & & 30 & 0.007 & 526.14 & 0.96 & 54.24 \\
\hline & \multirow[t]{3}{*}{10} & 10 & 0.006 & 581.66 & 0.99 & 30.13 \\
\hline & & 20 & 0.007 & 737.85 & 0.97 & 25.44 \\
\hline & & 30 & 0.005 & 644.8 & 0.97 & 49.85 \\
\hline & \multirow[t]{3}{*}{15} & 10 & 0.005 & 789.6 & 0.99 & 30.68 \\
\hline & & 20 & 0.006 & 1093 & 0.96 & 28.27 \\
\hline & & 30 & 0.005 & 850.8 & 0.96 & 43.85 \\
\hline & \multirow[t]{3}{*}{20} & 10 & 0.004 & 1086.6 & 0.95 & 33.03 \\
\hline & & 20 & 0.005 & 1915.75 & 0.98 & 28.15 \\
\hline & & 30 & & & & \\
\hline
\end{tabular}

the column before equilibrium occurred (Tan et al. 2008). The comparison of the experimental and predicted breakthrough curves obtained in the biosorption of CV by CLR and $C R$ at different flow rates $\left(10,15\right.$ and $\left.20 \mathrm{~mL} \mathrm{~min}^{-1}\right)$ at a constant bed depth $(10 \mathrm{~cm})$ according to the Thomas model is shown in Fig. 8a and b, respectively. From the figure, it was clear that there was a good agreement 

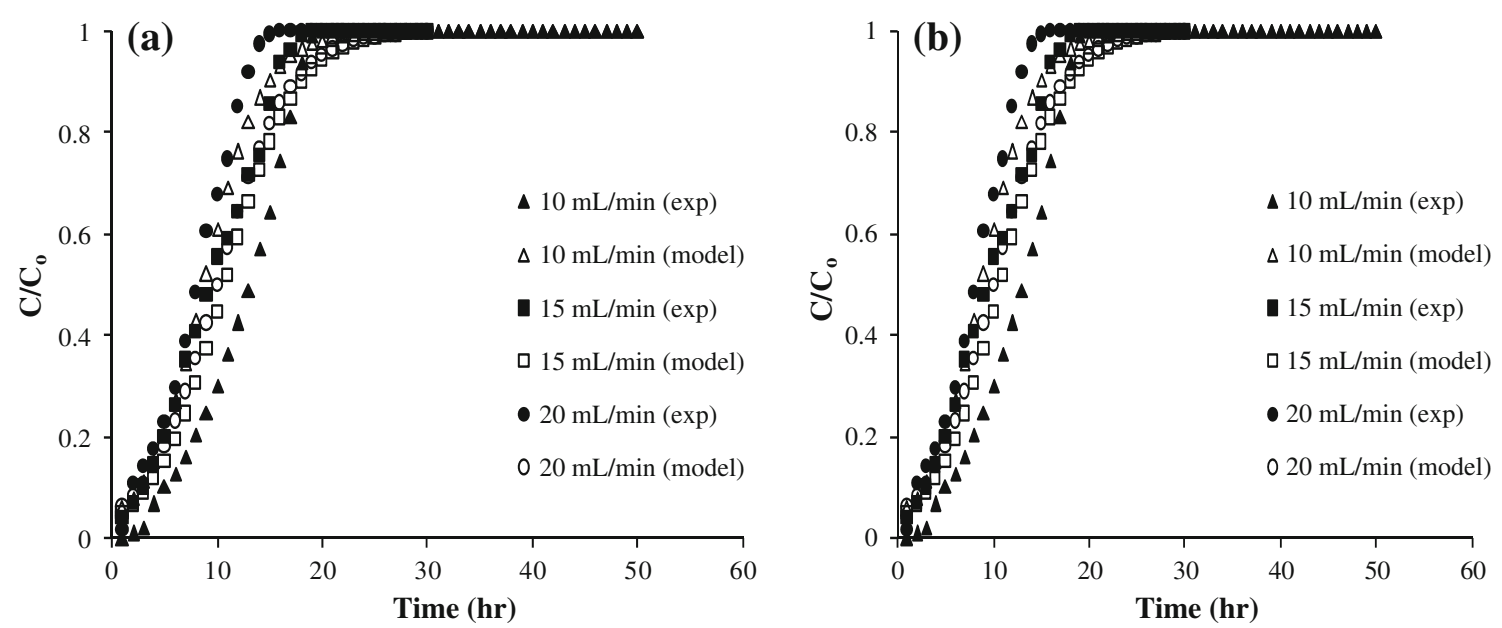

Fig. 9 Experimental and Yoon-Nelson model predicted breakthrough curves at $10 \mathrm{~cm}$ depth for different flow rates (initial CV concentration $=25 \mathrm{mg} \mathrm{L}^{-1}$ )

between the experimental points and model predicted values.

\section{Application of Yoon-Nelson model}

Yoon-Nelson model was also applied to the column data obtained from CV biosorption by CLR and CR. Linear regression was performed, and the values of the parameters Yoon-Nelson constant $\left(k_{\mathrm{YN}}\right)$ and $\tau$ (the time required for $50 \%$ sorbate breakthrough) were determined from the plot of $\ln \left(C / C_{0^{-}} C_{t}\right)$ versus time. The value of these calculated parameters are presented in Table 3. It was found that the experimental data exhibited good fit to the model with $R^{2}$, which was better in comparison to the Thomas model in both the cases (i.e., biosorption of CV by CLR and CR). The bed capacity was found to decrease with the increase in flow rate in the biosorption of CV by CLR and CR. The comparison of the experimental and predicted breakthrough curves obtained in the biosorption of CV by CLR and $\mathrm{CR}$ at different flow rates $\left(10,15\right.$ and $\left.20 \mathrm{~mL} \mathrm{~min}^{-1}\right)$ at a constant bed depth $(10 \mathrm{~cm})$ according to the Yoon-Nelson model is shown in Fig. 9a and b, respectively. From the figure, it was clear that there was a good agreement between the experimental points and model predicted values.

\section{Column regeneration and reuse studies}

The column with a bed depth of $10 \mathrm{~cm}$ and flow rate of $15 \mathrm{~mL} \mathrm{~min}{ }^{-1}$ saturated with $25 \mathrm{mg} \mathrm{L}^{-1}$ of $\mathrm{CV}$ was selected for this study. Desorption was carried out by $1 \mathrm{~N}$ $\mathrm{CH}_{3} \mathrm{COOH}$ solution through the bed in the downward flow direction at a flow rate of $13 \mathrm{~mL} \mathrm{~min}{ }^{-1}$, slightly less than the sorption flow rate $15 \mathrm{~mL} \mathrm{~min}{ }^{-1}$. The concentration of

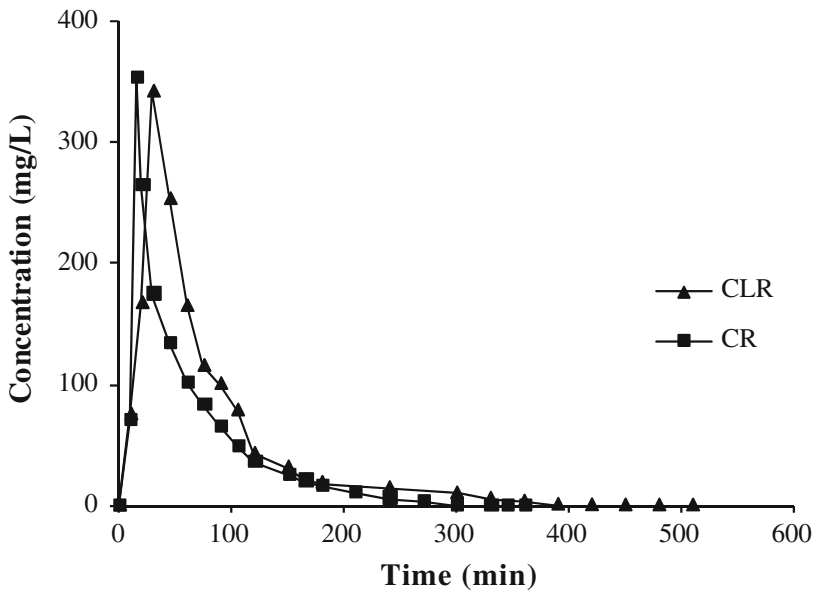

Fig. 10 First cycle desorption profile of CV

$\mathrm{CV}$ was monitored after different time interval as shown in the Fig. 10. It was observed that desorption cycle took $8.5 \mathrm{~h}$ for CLR and $6 \mathrm{~h}$ for CR, after which further desorption was negligible. The maximum concentration of $\mathrm{CV}$ was obtained at a contact time of $30 \mathrm{~min}$ for CLR and $15 \mathrm{~min}$ for CR and recorded as 342 and $353 \mathrm{mg} \mathrm{L}^{-1}$ which were 13.7 and 14.12 times higher than influent CV concentration. The eluting solution was low in volume and high in concentration, which could help in easy handling and recovery and reuse of $\mathrm{CV}$.

Comparison of sorption capacity of CLR and CR with other sorbents for the removal of $\mathrm{CV}$ in column mode

The use of low-cost, non-conventional sorbent for the removal of $\mathrm{CV}$ using column mode has not been paid much attention since now and thus very few literature is available 
Table 4 Comparison of sorption capacity of CLR and CR with other sorbents for the removal of dye in column mode

\begin{tabular}{|c|c|c|c|c|}
\hline Sorbent & Dye & Experimental conditions & $\begin{array}{l}\text { Sorption } \\
\text { capacity } \\
(\mathrm{mg} / \mathrm{g})\end{array}$ & References \\
\hline $\begin{array}{l}\text { Wheat straw modified by } \\
\text { carboxymethylation }\end{array}$ & Methylene blue & Influent concentration: $500 \mathrm{mg} / \mathrm{L} ; 5 \mathrm{~cm}$ & 209.9 & Zhang et al. (2011a) \\
\hline Peanut husk & Methylene blue & $\begin{array}{l}\text { Influent concentration: } 60 \mathrm{mg} / \mathrm{L} \text {; Flow rate: } \\
7.5 \mathrm{~mL} / \mathrm{min} \text {; bed height: } 10.5 \mathrm{~cm}\end{array}$ & 65.23 & Song et al. (2011) \\
\hline Capsicum anпиит & $\begin{array}{l}\text { Reactive Blue } \\
\quad 49\end{array}$ & $\begin{array}{l}\text { Influent concentration: } 100 \mathrm{mg} / \mathrm{L} \text {; flow rate: } \\
1 \mathrm{~mL} / \mathrm{min} \text {; bed height: } 9 \mathrm{~cm}\end{array}$ & 65.48 & Akar et al. (2011) \\
\hline Posidonia oceanica (L.) dead leaves & Methylene blue & $\begin{array}{l}\text { Influent concentration: } 100 \mathrm{mg} / \mathrm{L} \text {; flow rate: } \\
7.28 \mathrm{~mL} / \mathrm{min} \text {; bed height: } 9 \mathrm{~cm}\end{array}$ & 482.6 & Cavas et al. (2011) \\
\hline Palm shell activated carbon & Methylene blue & $\begin{array}{l}\text { Influent concentration: } 150 \mathrm{mg} / \mathrm{L} \text {; flow rate: } \\
20 \mathrm{~mL} / \mathrm{min} \text {; bed height: } 6 \mathrm{~cm}\end{array}$ & 133.13 & $\begin{array}{l}\text { Foo and Hameed } \\
\text { (2012) }\end{array}$ \\
\hline Oil palm empty fruit bunch & Rhodamine B & $\begin{array}{l}\text { Influent concentration: } 100 \mathrm{mg} / \mathrm{L} \text {; flow rate: } \\
5 \mathrm{~mL} / \mathrm{min} \text {; bed height: } 9 \mathrm{~cm}\end{array}$ & 69.86 & Auta (2012) \\
\hline Jackfruit leaf powder & Crystal violet & $\begin{array}{l}\text { Initial dye concentration: } 50 \mathrm{mg} / \mathrm{L} \text {, flow rate: } \\
10 \mathrm{~mL} / \mathrm{min}\end{array}$ & 61.469 & $\begin{array}{l}\text { Chakraborty et al. } \\
\text { (2011) }\end{array}$ \\
\hline Citric acid modified rice straw & Crystal violet & $\begin{array}{l}\text { Influent concentration: } 100 \mathrm{mg} / \mathrm{L} \text {; flow rate: } \\
5 \mathrm{~mL} / \mathrm{min} \text {; bed height: } 9 \mathrm{~cm}\end{array}$ & 77.185 & $\begin{array}{l}\text { Chakraborty et al. } \\
\text { (2011) }\end{array}$ \\
\hline Cyperus rotundus & Crystal violet & $\begin{array}{l}\text { Initial dye concentration: } 25 \mathrm{mg} / \mathrm{L} \text {, bed height: } \\
10 \mathrm{~cm} \text {, flow rate: } 10 \mathrm{~mL} / \mathrm{min}\end{array}$ & 54.24 & This study \\
\hline Citrullus lanatus rind & Crystal violet & $\begin{array}{l}\text { Initial dye concentration: } 25 \mathrm{mg} / \mathrm{L} \text {, bed height: } \\
10 \mathrm{~cm} \text {, flow rate: } 10 \mathrm{~mL} / \mathrm{min}\end{array}$ & 46.68 & This study \\
\hline
\end{tabular}

on the sorption of $\mathrm{CV}$ using the continuous column mode and also the direct comparison of sorption capacity is difficult with other sorbents because of different applied experimental conditions. The comparison of sorption capacities of CLR and CR with other sorbents for the removal of $\mathrm{CV}$ in column mode is shown in Table 4 . The results revealed that CLR and CR are promising biosorbents for the removal of $\mathrm{CV}$ from aqueous solution.

\section{Conclusion}

This study confirmed that the freely, locally and abundantly available agricultural wastes, Citrullus lanatus rind and Cyperus rotundus, could be used as an alternate to the commercial activated carbon for the removal of $\mathrm{CV}$ from aqueous solution. The sorption of $\mathrm{CV}$ was strongly dependent on the bed height, flow rate and initial dye concentration. An increase in bed height resulted in improved sorption performance. With the increase in flow rates, the uptake capacity was found to decrease. The increase in initial dye concentration resulted in higher uptake. A maximum uptake of 46.68 and $54.24 \mathrm{mg} \mathrm{g}^{-1}$ for $\mathrm{CV}$ biosorption by CLR and CR, respectively, was

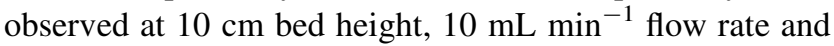
$25 \mathrm{mg} \mathrm{L}^{-1}$ initial dye concentration. The BDST model was used to predict the relationship between service time and bed height, which is essential in column process design. The experimental data fitted well to the BDST model.
The bed sorption capacity $\left(N_{0}\right)$ was found to be 5.02 and $4.54 \mathrm{mg} \mathrm{L}^{-1}$ for CV biosorption by CLR and CR, respectively. The BDST model was also applied for the successful prediction of design parameters at different flow rates. Thomas and Yoon-Nelson models were also applied to the data, and the Yoon-Nelson model provided better descriptions of the experimental kinetic data in comparison to the Thomas model. Desorption studies were carried out by $1 \mathrm{~N} \mathrm{CH}_{3} \mathrm{COOH}$ solution through the bed in the downward direction at a flow rate of $13 \mathrm{~mL} \mathrm{~min}^{-1}$. It was observed that desorption cycle took $8.5 \mathrm{~h}$ for CLR and $6 \mathrm{~h}$ for CR, after which desorption was negligible.

Open Access This article is distributed under the terms of the Creative Commons Attribution License which permits any use, distribution, and reproduction in any medium, provided the original author(s) and the source are credited.

\section{References}

Ahmad R (2009) Studies on adsorption of crystal violet dye from aqueous solution onto Coniferous. Pinus Bark Powder (CPBP). J Hazard Mater 171:767-773

Ahmad AA, Hameed BH (2010) Fixed-bed adsorption of reactive azo dye onto granular activated carbon prepared from wastes. J Hazard Mater 175:298-303

Ahmad MA, Rahman NK (2011) Equilibrium, kinetics and thermodynamic of Remazol Brilliant Orange 3R dye adsorption on coffee husk-based activated carbon. Chem Eng J 170:154-161

Akar ST, Gorgulu A, Akar T, Celik S (2011) Decolorization of reactive blue 49 contaminated solution by Capsicum annuum

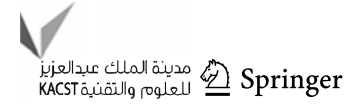


seeds: batch and continuous mode biosorption applications. Chem Eng J 168:125-133

Alencar WS, Acayanka E, Lima EC, Royer B, Desouza FE (2012) Application of Mangifera indica (mango) seeds as biosorbent for removal of Victazol orange 3R dye from aqueous solution and study of the biosorption mechanism. Chem Eng J 209:577-588

Arulkumar M, Sathishkumar P, Palvannan T (2011) Optimization of Orange $G$ dye adsorption by activated carbon of Thespesia populnea pods using response surface methodology. J Hazard Mater 186:827-834

Auta M (2012) Fixed bed adsorption studies of Rhodamine B dye using oil palm empty fruits bunch activated carbon. J Eng Res Stud 3:3-6

Auta M, Hameed BH (2011) Preparation of waste eta activated carbon using potassium acetate as an activating agent for adsorption of Acid blue 25 dye. Chem Eng J 171:502-509

Banat IM, Nigam P, Singh D, Marchant R (1996) Microbial decolorization of textile-dye containing effluents: a review. Bioresour Technol 58:217-227

Batzias FA, Sidiras DK (2004) Dye adsorption by calcium chloride treated beech sawdust in batch and fixed-bed systems. J Hazard Mater B 114:167-174

Cavas L, Karabay Z, Alyuruk H, Dogan H, Demir GK (2011) Thomas and artificial neural network models for the fixed-bed adsorption of methylene blue by a beach waste Posidonia oceanic (L.) dead leaves. Chem Eng J 171:557-562

Chakraborty S, Chowdhury S, Saha PD (2011) Adsorption of Crystal violet from aqueous solution onto $\mathrm{NaOH}$-modified rice husk. Carbohydr Polym 86:1533-1541

Cheknane B, Badu M, Basly JP, Bouras O, Zermane F (2012) Modeling of basic green 4 dynamic sorption onto granular organo-inorgano pillared clays (GOICs) in column reactor. Chem Eng J 209:7-12

Chowdhury S, Saha PD (2013) Artificial neural network (ANN) modeling of adsorption of methylene blue by $\mathrm{NaOH}$-modified rice husk in a fixed-bed column. Environ Sci Pollut Res 20:1050-1058

Chowdhury S, Chakraborty S, Saha PD (2011a) Biosorption of Basic green 4 from aqueous solution by Ananas cosmosus (pineapple) leaf powder. Coll Surf B Bio inter 84:520-527

Chowdhury S, Mishra R, Saha P, Kushwaha P (2011b) Adsorption thermodynamics, kinetics and isosetric heat of adsorption of malachite green onto chemically modified rice husk. Desalination 265:159-168

Christie R (2001) Color chemistry. The Royal Society of Chemistry, Cambridge

Deniz F, Karaman S (2011) Removal of Basic red 46 dye from aqueous solution by pine tree leaves. Chem Eng J 170:67-74

Dotto GL, Pinto LAA (2011) Adsorption of food dyes acid blue 9 and food yellow 3 onto chitosan: stirring rate effect in kinetics and mechanism. J Hazard Mater 187:164-170

Elkady MF, Ibrahim AM, El-Latif MMA (2011) Assessment of the adsorption kinetics, equilibrium and thermodynamic for the potential removal of reactive dye using eggshell bio-composite beads. Desalination. doi:10.1016/2011.05.063

El-Sayed GO (2011) Removal of methylene blue and crystal violet from aqueous solutions by palm kernel fiber. Desal 272:225-232

Fan L, Zhou Y, Yang W, Chen G, Yang F (2008) Electro-chemical degradation of aqueous solution of Amaranth azo dye on ACF under potentiostatic model. Dyes Pigments 76:440-446

Farooq U, Kozinski JA, Khan MA, Athar M (2010) Biosorption of heavy metal ions using wheat based bio-adsorbents. Bioresour Technol 101:5043-5053

Foo KY, Hameed BH (2012) Dynamic adsorption behavior of methylene blue onto oil palm shell granular activated carbon prepared by microwave heating. Chem Eng J 203:81-87
Goel J, Kadirvelu K, Rajagopal C, Garg VK (2005) Removal of Lead (II) by adsorption using treated granular activated carbon: batch and column studies. J Hazard Mater 125:211-220

Hamdaoui O (2006) Dynamic sorption of methylene blue by cedar sawdust and crushed brick in fixed bed columns. J Hazard Mater B138:293-303

Hameed BH, Ahmad AA (2009) Batch adsorption of methylene blue from aqueous solution by garlic peel, an agricultural waste. J Hazard Mater 164:870-875

Hameed BH, El-Khaiary MI (2008) Removal of basic dye from aqueous medium using a novel waste material: pumpkin seed hull. J Hazard Mater 155:601-609

Hameed BH, Mahmoud DK, Ahmad AL (2008) Equilibrium modeling and kinetic studies on the adsorption of basic dye by a lowcost adsorbent: coconut (Cocos nucifera) bunch waste. J Hazard Mater 158:65-72

Han R, Ding D, Xu Y, Zou W, Wang Y, Li Y, Zou L (2008) Modified mesoporous clay adsorbent for adsorption isotherm and kinetics of methylene blue. Bioresour Technol 99:2938-2946

Han R, Wang Y, Zhao X, Wang Y, Xie F, Cheng J, Tang M (2009) Adsorption of methylene blue by Phoenix tree leaf powder in a fixed-bed column: experiments and prediction of breakthrough curves. Desal 245:284-297

Hasan SH, Ranjana D, Talat M (2010) Agro-industrial waste wheat bran for the biosorptive remediation of selenium through continuous up-flow fixed-bed column. J Hazard Mater 181:1134-1142

Kara I, Akar ST, Akar T, Ozcan A (2012) Dithicarbamated symphoricarpus albus as a potential biosorbent for a reactive dye. Chem Eng J 211-212:442-452

Kumar R, Ahmad R (2011) Biosorption of hazardous crystal violet dye from aqueous solution onto treated ginger waste (TGW). Desalination 265:112-118

Kumar S, Gunasekaran V, Pnnusami V (2013) Removal of Methylene blue from aqueous effluent using fixed bed of groundnut shell powder. J Chem. doi:10.1155/2013/259819

Kundu S, Gupta AK (2006) As (III) removal from aqueous medium in fixed bed using iron-oxide coated cement (IOCC): experimental and modeling studies. Chem Eng J 122:93-106

Low KS, Lee CK (1991) Cadmium uptake by the Moss, Calymperes delesserti Besch. Bioresour Technol 38:1-6

Martín-Lara MA, Hernáinz F, Blázquez G, Tenorio G, Calero M (2010) Sorption of Cr(VI) onto Olive Stone in a packed bed column: Prediction of kinetic parameters and breakthrough curves. J Environ Eng 136:1389-1397

Mohd Azmier A, Nazira Khabibor R (2011) Equilibrium, kinetics and thermodynamic of Remazol Brilliant Orange 3R dye adsorption on coffee husk-based activated carbon. Chem Eng J 170:154-161

Odha B, Chaudhari S (2007) Effect of electro-fenton application on azo dyes biodegradability. J Hazard Mater 148:459-466

Patel H, Vashi RT (2012) Fixed bed column adsorption of Acid yellow 17 dye onto Tamarind seed powder. Can J Chem Eng 90:180-185

Qi Z, Wenqi G, Chuanxin X, Dongjiang Y, Xiaoqing L, Xiao Y (2011) Removal of neutral red from aqueous solution by adsorption on spent cottonseed hull substrate. J Hazard Matr 185:502-506

Ramesh ST, Gandhimathi R, Nitheesh PV, Nagendra B, Bharathi KS (2011) Breakthrough data analysis of adsorption of Cd (II) on Coir pith column. Electro J Environ Agri Food Chem 10(7):2487-2505

Reddy MCS, Sivaramakrishna L, Reddy AV (2012) The use of an agricultural waste material, Jujuba seeds for the removal of anionic dye (Congo red) from aqueous medium. J Hazard Mater 203-240:118-127 
Saeed A, Sharif M, Iqbal M (2010) Adsorption potential of grape fruit peel as dye sorbent: kinetics, equilibrium and mechanism of Crystal violet adsorption. J Hazard Mater 179:564-572

Safa Y, Bhatti HN (2011) Adsorptive removal of direct textile dyes by low cost agricultural waste: application of factorial design analysis. Chem Eng J 167:35-41

Saha PD, Chowdhury S, Mondal M, Sinha K (2011) Sep Sci Technol. doi:10.1080/01496395.2011.610397

Sayan E (2006) Optimization and modeling of decolorization and COD reduction reactive dye by ultrasound-assisted adsorption. Chem Eng J 119:175-181

Senthilkumar P, Ramalingam S, Senthamarai C, Niranjanaa M, Vijayalakshmi M, Sivanesan M (2010) Adsorption of dye from aqueous solution by cashew nut shell: studies on equilibrium isotherm, kinetics and thermodynamics of interactions. Desalination 261:52-60

Singh TS, Panat KK (2006) Experimental and modeling studies on fixed bed adsorption of As (III) removal from aqueous solution. Sep Purif Technol 48:288-298

Sivakumar P, Palanisamy PN (2009) Adsorptive removal of reactive and direct dyes using non-conventional adsorbent-column studies. J Sci Ind Res 68:894-899

Sleiman M, Vildozo DL, Ferronato C, Chovelon JM (2007) Photocatalytic degradation of patent blue $\mathrm{v}$ by supported TiO: kinetics, mineralization and reaction pathway. Appl Catal B 77:1-11

Sohrabi MR, Ghavami M (2008) A novel agricultural waste adsorbent for the removal of cationic dye from aqueous solutions. J Hazard Mater B 153:1235-1239

Song J, Zou W, Bian Y, Su F, Han R (2011) Adsorption characteristics of methylene blue by peanut husk in batch and column modes. Desalination 265:119-125

Tamer A, Sema C, Sibel Tunali A (2010) Biosorption performance of surface modified biomass obtained from Pyracantha coccinea for the decolorization of dye contaminated solutions. Chem Eng J 160:466-472

Tan IAW, Ahmad AL, Hameed BH (2008) Adsorption of basic dye using activated carbon prepared from oil palm shell: batch and fixed bed studies. Desalination 225:13-28

Tanyildizi MS (2011) Modeling of adsorption isotherms and kinetics of reactive dye from aqueous solution by peanut hull. Chem Eng J 168:1234-1240
Taty-Costodes VC, Fauduet H, Porte C, Ho YS (2005) Removal of lead (II) ions from synthetic and real effluents using immobilized Pinus sylvestris sawdust: Adsorption on fixed bed column. J Hazard Mater B 123:135-144

Tunc O, Tanaci H, Aksu Z (2009) Potential use of cotton plant wastes for the removal of Remazol Black B reactive dye. J Hazard Mater 163:187-198

Upendra K, Manas B (2006) Fixed bed column study for Cd (II) removal from wastewater using treated rice husk. J Hazard Mater B 129:253-259

Vijayaraghavan K, Prabu D (2006) Potential of Sargassum wightii biomass for copper (II) removal from aqueous solution: application of different mathematic models to batch and continuous biosorption data. J Hazard Mater B 137:558-564

Vijayaraghavan K, Jegan J, Palanivelu K, Velan M (2004) Removal of nickel (II) ions from aqueous solution using crab shell particles in a packed bed up-flow column. J Hazard Mater 113:223-230

Weng CH, Lin YT, Tzeng TW (2009) Removal of methylene blue from aqueous solution by adsorption onto pineapple leaf powder. J Hazard Mater 170:417-424

Wu JS, Liu CH, Chu KH, Suen SY (2008) Removal of cationic dye methyl violet $2 \mathrm{~B}$ from water by cation exchange membranes. J Membr Sci 309:239-245

Zaghbani MX, Lee L, Wang HH, Wang Z (2007) Adsorption of methylene blue on low-cost adsorbents: a review. J Hazard Mater 149:735-741

Zaghbani N, Hafiane A, Dhahbi M (2008) Removal of Safranin T from wastewater using micellar enhanced ultrafiltration. Desalination 222:348-356

Zhang W, Yan H, Jiang Z, Dong L, Kan X, Yang H, Li A, Cheng R (2011a) Removal of dyes from aqueous solutions by straw based adsorbents: batch and column studies. Chem Eng J 168:1120-1127

Zhang Z, Moghaddam L, Hara IM, Doherty WOS (2011b) Congo red adsorption by ball-milled sugarcane bagasse. Chem Eng $\mathrm{J}$ 178:122-128

Zhong QQ, Yue QY, Li Q, Xu X, Gao BY (2011) Preparation, characterization of modified wheat residue and its utilization for the anionic dye removal. Desalination 267:193-200 